\title{
Językowa tożsamość uczestników komunikacji internetowej. Na przykładzie grupy dyskusyjnej
}

\author{
Linguistic identity of the Internet communication users. \\ On the example of the discussion group
}

\author{
Jakub Płowens \\ Instytut Językoznawstwa, Uniwersytet im. Adama Mickiewicza \\ al. Niepodległości 4, 61-874 Poznań \\ jakubplowenseo2.pl
}

\begin{abstract}
This article describes language communication of the Internet discussion group. Linguistic material derives from the fans' discussion group dedicated to one of the most famous Bulgarian rock bands called E.T.P. (B. T. R.). In order to present language behaviours and subsequent relationships between users, interdisciplinary methods were applied in an analysis of the group's language. The objective of this article is to find the social character that reveals itself in the language (linguistic identity) of the users' environment. The article proves the existence of the value-system that enables an attribution of the organisational culture's features into the community of the discussion group users.
\end{abstract}

\section{Wprowadzenie}

Artykuł stanowi rewizję i rozwinięcie niektórych zagadnień poruszonych w mojej pracy magisterskiej ${ }^{1}$. Interesować nas będzie charakterystyka procesu komunikacji w środowisku internetowej grupy dyskusyjnej ${ }^{2}$. Postaramy się wskazać zachowania językowe uczestników dyskursu na forum internetowym, co doprowadzi nas nie tylko do zaobserwowania uzusu grupy dyskusyjnej, lecz także do odnotowania niektórych konsekwencji komunikacji językowej w elektronicznym świecie ${ }^{3}$ Internetu. Trzeba zaznaczyć, że skutki komunikacji będziemy rozpatrywać pod względem normatywnym, socjologicznym i socjolingwistycznym, pragmalingwistycznym oraz psycholingwistycznym.

\footnotetext{
${ }^{1}$ Zob. Komunikacja w sieci. Język butgarski w Internecie (na przykładzie grupy dyskusyjnej), Poznań 2007. Praca powstała w Katedrze Filologii Słowiańskich (obecnym Instytucie Filologii Słowiańskiej) na Wydziale Filologii Polskiej i Klasycznej UAM.

${ }^{2}$ Oprócz terminu grupa dyskusyjna będę stosował wymiennie termin forum (internetowe).

${ }^{3} \mathrm{~W}$ literaturze bardzo często wyrażenia typu wirtualny, cyfrowy, elektroniczny świat itp. traktuje się jako synonimy Internetu.
} 
Niewątpliwie interdyscyplinarne podejście w badaniach nad językowymi procesami komunikacyjnymi w Internecie jest uzasadnione i konieczne, jeśli stawiamy sobie za cel odkrycie zjawisk społecznych, związanych z posługiwaniem się kodem języka. Dość powiedzieć, że język służy w Internecie za podstawowy kod komunikacyjny, a wszelkie inne kody pełnią względem niego funkcję uzupełniającą i "wzbogacającą" porozumiewanie się. Przyjmujemy w tej pracy, że sytuacje komunikacyjne występujące w Internecie potwierdzają część hipotezy Sapira-Whorfa, wedle której ,język określonej ludzkiej zbiorowości, będący jej tworem, narzędziem myślenia i komunikowania się, organizuje sposób postrzegania świata i w związku z tym kształtuje świat" (Grabias 2003: 47).

Materiał językowy pochodzi z grupy dyskusyjnej miłośników jednego z bardziej znanych bułgarskich zespołów rockowych - Б.T.P. Funkcjonuje ona jako integralna część strony internetowej www.btr.cc. Forum skupia użytkowników w różnym wieku, częściej ludzi młodych. Podejmują oni tematykę związaną przede wszystkim z poczynaniami zespołu. Opisywane są aktualne wydarzenia muzyczne, jak np. koncerty, wydanie nowego albumu; dyskutuje się o poszczególnych członkach zespołu, tekstach piosenek, a niekiedy również o bieżących wydarzeniach, które nie mają nic wspólnego z tematyką grupy (np. mecze piłki nożnej).

\section{Uwiklania komunikacyjne w internetowej grupie dyskusyjnej}

Pod pojęciem tożsamości kryją się językowe zachowania użytkowników grupy oraz wypływające $\mathrm{z}$ nich relacje między użytkownikami. Fenomen każdej grupy internetowej polega na zrzeszaniu się ludzi o podobnych zainteresowaniach nie tylko po to, by wymieniać informacje stanowiące tematykę danej grupy, lecz także w celu wzajemnego zapoznania się, wymiany poglądów, mówiąc zwięźle - zbudowania stabilnej i ciągle rozwijającej się społeczności. Poszukiwać tożsamości powinniśmy zatem w tekstach umieszczonych na forum, $\mathrm{z}$ nich bowiem pozyskuje się wiele cennych wiadomości o grupie i jej uczestnikach. Są one trwałym śladem, ukazują nam m.in. idiolekty autorów i ich myśli oraz pewne właściwości języka całej społeczności.

Jednym z zadań na drodze do ukazania społecznego charakteru komunikacji w grupie dyskusyjnej będzie możliwie precyzyjne jej zdefiniowanie. P. Mazurek określa grupę dyskusyjna , jako system asynchronicznej (korespondencyjnej, e-mailowej - J.P.) wymiany komunikatów hipertekstowych, dokonującej się za pośrednictwem Internetu, charakteryzującej się tym, że każdy uczestnik ma możliwość zarówno odbierania, jak i nadawania komunikatów" (Mazurek 2005: 104). W opisie grupy musimy zaznaczyć, iż tworzą ją wyłącznie zarejestrowani użytkownicy, którzy mogą komunikować się, pisząc posty (ilustracja $\mathrm{nr}$ 1) wchodzące w skład poszczególnych tematów, których spis (ilustracja nr 2) odnajdziemy na stronach internetowych każdej grupy dyskusyjnej. 


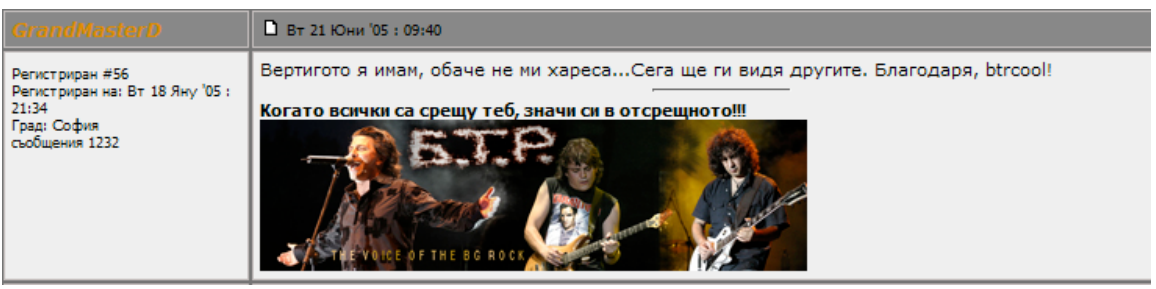

Ilustracja 1. Przyktadowy post grupy dyskusyjnej zespotu Б.T.P.

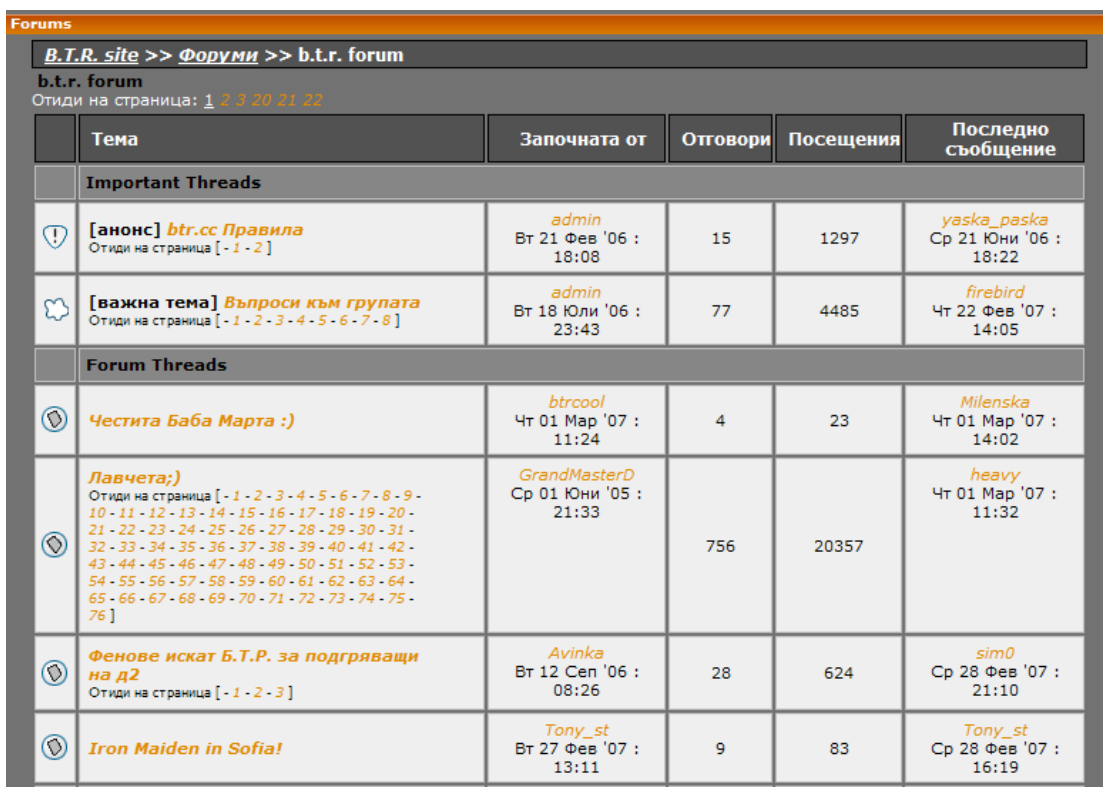

Ilustracja 2. Lista poruszanych tematów (fragment).

Komunikowanie się w grupie dyskusyjnej jest procesem regulowanym istnieniem tzw. netykiety, stanowiącej swoistą „konstytucję” danej grupy. Wyznacza ona nie tylko towarzyskie konwenanse w społeczności grupy, ale niekiedy określa też jej cele. Netykieta potwierdza funkcjonowanie $\mathrm{w}$ grupie systemu wartości, który należy rozumieć jako zespół reguł, dzięki którym użytkownicy identyfikują się i mogą być identyfikowani z konkretna grupą dyskusyjną. System ma charakter umowy, którą respektują wszyscy użytkownicy. P. Mazurek definiuje system wartości znacznie dokładniej, mianowicie, jako element kultury grupy, czyli wypracowanego przez użytkowników systemu aksjonormatywnego. Poza systemem wartości, który wyznacza główne idee przyświecające istnieniu grupy, wyróżniamy także system normatywny, który reguluje wzory zachowania (por. Mazurek 2005: 109-111). Netykieta powinna opierać się na wyróżnionych systemach. W wypadku omawianej tu grupy mamy netykietę (ilustracja nr 3) reprezentującą bardziej system normatywny, nie przewidziano bowiem celu grupy, co jest z jednej strony zrozumiałe, ponieważ uczestnicy tego forum powinni wiedzieć, dlaczego dołączyli do jego społeczności, powinni m.in. wspierać swój ulubiony zespół, komentować wydarzenia muzyczne z jego udziałem itp., z drugiej jednak strony im precyzyjniejszy będzie statut (netykieta), tym więcej będzie do dyspozycji środków rozwiązywania ewentualnych kwestii spornych (odchyleń od statutu). Dodajmy, że nad należytym przestrzeganiem netykiety czuwa administrator. 


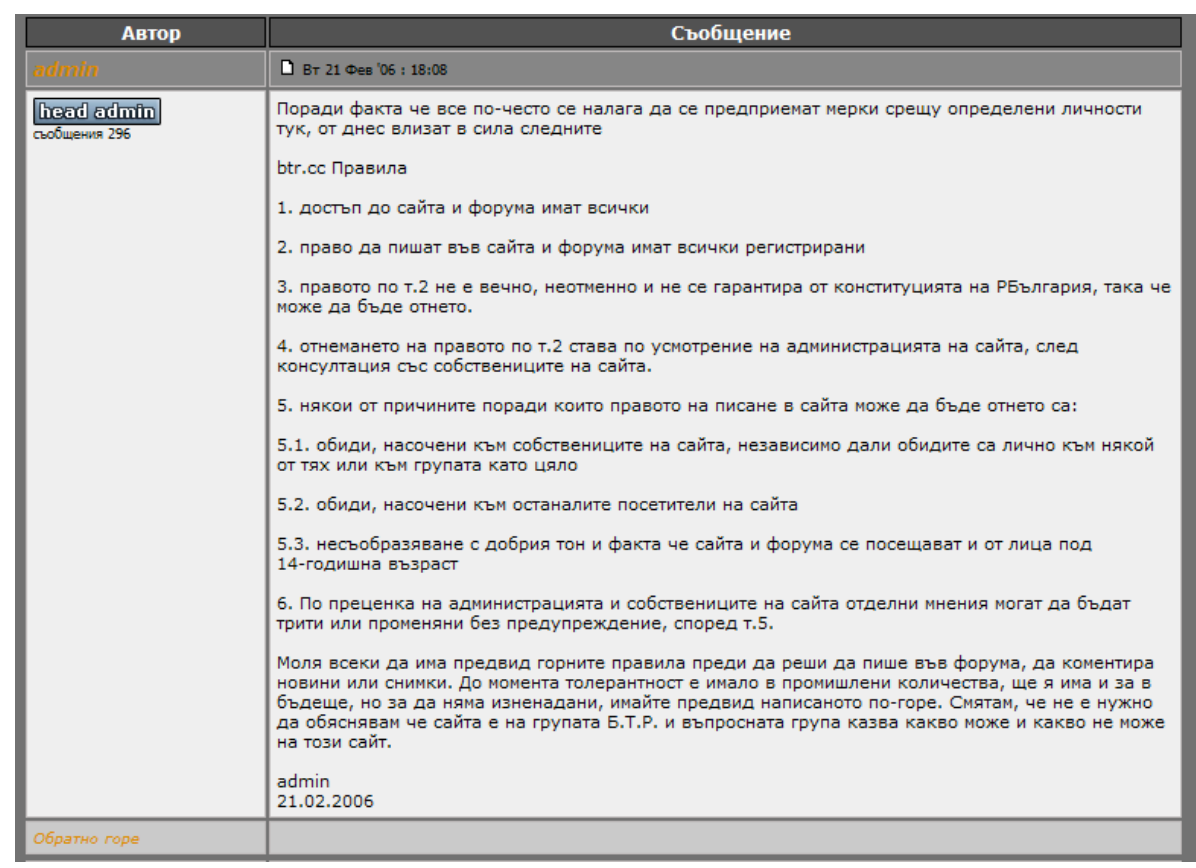

Ilustracja 3. Netykieta grupy dyskusyjnej zespotu B.T.P.

Należy zwrócić uwagę na specyficzny styl języka netykiety. Umieszczona w nagłówku konstrukcja składniowa oт днес влизат в сила следните (правила - J.P.) odsyła nas do stylu urzędowego. Sprecyzowano, kto ma dostęp do forum: достъn до сайта и форума имат всички oraz, kto może brać udział w dyskusjach: право да пишат във сайта $u$ форума имат всички регистрирани. Oprócz tego w treści netykiety wyjaśniono, iż uczestnictwo w społeczności (grupie dyskusyjnej) jest regulowane odgórnie (przez administratora strony), zatem prawo do uczestnictwa może zostać w pewnych (również wymienionych) sytuacjach odebrane: правото (nо т.2) не е вечно, неотменно и не се гарантира от конституцията на РБългария, така че може да бъде отнето. Netykieta opiera się na zaledwie kilku bardzo prostych przepisach. W głównej mierze chodzi o kulturę słowa (niedopuszczalne jest wzajemne obrażanie się, a co za tym idzie, używanie wulgaryzmów) oraz przestrzeganie granicy wieku (rejestracji moga dokonać osoby, które ukończyły 14 lat). Z punktu widzenia kultury języka netykieta może spełniać w Internecie nader ważną rolę, ponieważ zakazując posługiwania się inwektywami oraz wulgaryzmami, wywiera wpływ na przestrzeganie przyzwoitego stylu. W rzeczonej netykiecie zabrakło co prawda punktu, w którym wyraźnie byłaby mowa o poszanowaniu poprawności językowej i stylistycznej, jednak zdarzają się takie sytuacje, w których użytkownicy wypowiadają się na temat kultury języka. Z zamieszczonego poniżej tekstu wynika, że kultura języka niekoniecznie przejawia się w językowym puryzmie, lecz jest ona raczej związana z zagadnieniem tożsamości środowiska grupy dyskusyjnej. Niemniej jednak tożsamość trzeba pojmować nie tylko w kategoriach przynależność do konkretnej grupy społecznej, lecz przede wszystkim jako przynależność do bułgarskiej przestrzeni kulturowej, a tym samym językowej. Przyjrzyjmy się rozmowie, kiedy na forum pojawia się nowy użytkownik. 


\begin{tabular}{|c|c|}
\hline drujba_i & $\begin{array}{l}\text { az sam ot dnes tuk, iskam da kaja che ne sam pochitatel na tazi muzika, a } \\
\text { BTR e edinstvenoto koeto sam slushala i shte slusham, nyama drugi v BG! da } \\
\text { im chestito dnes na rojdenicite, te si znayat koi sa:) chestito sanya!!!!!:) }\end{array}$ \\
\hline badmarto & $\begin{array}{l}\text { ми честито да им е :) } \\
\text { И добре дошла във форума! }\end{array}$ \\
\hline drujba_i & mersi!:)) \\
\hline Gluscevic $®$ & Добре дошла и ще те помоля да пишеш на кирилица ;) \\
\hline btrcool & $\begin{array}{l}\text { Добре дошла!!! :))) } \\
\text { Ле ле много фенове станахме вече в този сайт - радвам се!!! :))) }\end{array}$ \\
\hline Mime & 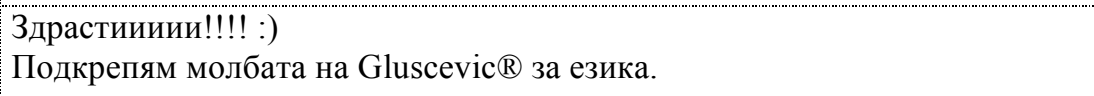 \\
\hline drujba_i & каква и пък има на латиницата?:) \\
\hline Gluscevic $®$ & $\begin{array}{l}\text { Ако пишеше на английски - нищо, но аз лично не знам да има български } \\
\text { език с латински букви. Чете се по-трудно и от уважение към другите } \\
\text { потребители и езика ни всички тук пишем на кирилица. Все пак живеем } \\
\text { в България, нали? }\end{array}$ \\
\hline$B T R \_f$ & Добре дошла и от мен ;) \\
\hline proxy & Амчи като сте почнали, нека и аз да поздравя :) Здрасти, как си? :))) \\
\hline st_pavlusha & $\begin{array}{l}\text { Добре дошла! А това с музиката не е фатално. Щом си се добрала до } \\
\text { тозисайт има надежда да стане човек и от теб:-) Надявам се не си } \\
\text { тънкообидна това е майтап, но и истина }\end{array}$ \\
\hline viki88 & добре дошла и от мен:):):) \\
\hline drujba_i & $\begin{array}{l}\text { леле, ама тук хората са много гостоприемни:) благодаря на всички! а } \\
\text { това с за латиницата не съм много съгласна, ама от мен да мине:) }\end{array}$ \\
\hline
\end{tabular}

\section{hahahahahaha: $)^{4}$}

Nowy użytkownik o pseudonimie (czyli tzw. nicku - od ang. nickname 'przezwisko'; zob. Pisarek 2006: 129) drujba_i przedstawia się na forum, używając przy tym nie do końca poprawnych reguł transliteracji ( $z h$ zamiast $j$ na oznaczenie $x$; ts zamiast $c$ na oznaczenie u) $)^{5}$. Na wypowiedź nowego użytkownika odpowiada badmarto i pozdrawia zdaniem $U$ добре дошла във форума! Podobnie czyni Gluscevic ${ }^{\circledR}$, jednak zaraz po tym zwraca nowemu użytkownikowi uwagę, pisząc: ще те помоля да пишеш на кирилица ;). Sądząc po użytym emotikonie ${ }^{6}$, Gluscevic ${ }^{\circledR}$ pragnie tylko taktownie zasygnalizować potrzebę

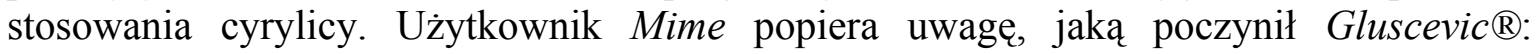
Подкрепям молбата на Gluscevic ${ }^{\circledR}$ за езика. Takie zachowanie innych członków grupy

\footnotetext{
${ }^{4}$ Za każdym razem będę podawał odnośnik w postaci nazwy tematu, w którym zamieszczono cytowane wypowiedzi. We wszystkich przykładach zachowuję oryginalną pisownię i interpunkcję.

${ }^{5}$ Odnotujmy, że chociaż nowe zasady transliteracji (wprowadzone przez Bułgarską Akademię Nauka na początku 2006 roku) są powszechnie dostępne $\mathrm{w}$ Internecie, to wiele osób posługuje się niegdyś wyuczonym nieskodyfikowanym systemem transliteracji, np. spółgłoskę 4 oznacza się cyfrą 4 , a $u$ cyfrą 6 . To ciekawy, lecz normatywnie błędny, przykład przenoszenia wartości dźwiękowej głoski szumiącej na znak matematyczny, któremu również odpowiada leksem rozpoczynający się od tych samych głosek 4- четири, 6- шест.

${ }^{6}$ Rolę emotikonów omówimy w dalszej części tego artykułu.
} 
dyskusyjnej może być odczytywane już jako próba realizacji panującego na forum systemu normatywnego; spójrzmy na treść kolejnej wypowiedzi: Ако пишеше на английски нищзо, но аз лично не знам да има български език с латински букви. Чете се потрудно и от уважение към другите потребители и езика ни всички тук пишем на кирилица. Все пак живеем в България, нали? W tym komunikacie Gluscevic ${ }^{\circledR}$ podkreśla (nieco ironicznie), że w języku bułgarskim używa się alfabetu cyrylickiego. Co więcej, tłumaczy, że stosowanie liter łacińskich utrudnia czytanie postów i ze względu na szacunek dla innych użytkowników wypada pisać cyrylicą. Mamy tu do czynienia z przykładem praktycznego zastosowania norm systemu aksjonormatywnego, które bezsprzecznie uznaje całe środowisko grupy dyskusyjnej. W tym miejscu została zaakcentowana tożsamość narodowa tej grupy. Wydaje się, że kwestie przynależności narodowej stoją ponad kwestiami poprawności gramatycznej i stylistycznej. Tożsamość tej grupy ujawnia się poprzez używanie cyrylicy, która jest alfabetem języka bułgarskiego. Warstwa stylistyczna tekstów na forum jest rzeczą drugorzędną; tak naprawdę liczy się komunikatywność treści przekazywanych w postach. Język spełnia rolę nośnika informacji - nie ma tu wartości stylistycznej na takim poziomie, jak np. w literaturze pięknej. Z tego względu dominuje bardzo swobodny, potoczny styl.

Wydaje się również, że pewne normy i wartości funkcjonują w świadomości użytkowników, nawet jeśli nie zostały one zapisane w netykiecie. Ukazuje to kolejny fragment tego samego dyskursu.

\begin{tabular}{|l|l|}
\hline drujba_i & $\begin{array}{l}\text { mno smeshno:) imah predvid, che predi dosta godini, kogato horata } \mathrm{v} \text { bg edva } \\
\text { opoznavaha ineta i inet obshtuvaneto, se izpolzvashe samo latinicata, zashtoto } \\
\text { e udobna za vsichki, nezavisimo ot kade pishat. ta prosto star i losh navik: })\end{array}$ \\
Gluscevic ${ }^{\circledR}$ & $\begin{array}{l}\text { Еми ако един навик навик е по-силен от желанието ти да уважаваш } \\
\text { родния си език и да улесниш другите потребители с четенето, пиши на } \\
\text { латиница. Все пак щом не е написано в правилата, никой не те задължава } \\
\text { да го правиш. Просто помолих ;) }\end{array}$
\end{tabular}

Gluscevic ${ }^{\circledR}$ konsekwentnie thumaczy, że pisanie cyrylicą podyktowane jest szacunkiem wobec języka, mimo że nie wyszczególniono tego w netykiecie. Ironicznie krytykuje stosowanie transliteracji, która w pewnym sensie zaburza tożsamość języka bułgarskiego.

W przywołanym fragmencie rozmowy można dostrzec istotny element kulturotwórczy, tj. swego rodzaju akt przyjęcia nowej osoby do społeczności użytkowników. Bez wątpienia grupa dyskusyjna upodabnia się do organizacji (wspólnoty) społecznej. Można wręcz postawić hipotezę, wedle której grupa dyskusyjna odzwierciedla sieciowe społeczeństwo (proponuje się tu termin on-line community, zob. Olejnik 2005: 232), co znajduje potwierdzenie w refleksjach badaczy. „Internet definiowany jako społeczność, wspólnota ludzi używających i rozwijających sieć może budzić nasze zastrzeżenia - grupa użytkowników jest wówczas wspólnotą społeczną. Jednak, jeśli spojrzeć na Internet jako medium komunikacyjne - to można określić komunikowanie się poprzez Sieć jako uczestnictwo w życiu społecznym" (Lipińska 2004: 267). Grupa w takim ujęciu ma swoją kulturę organizacyjna, o czym świadczy już choćby akceptowany przez wszystkich członków system aksjonormatywny. To on przede wszystkim buduje kulturę organizacyjną - jest jej podstawowym wyznacznikiem (por. Lipińska 2004: 329).

$\mathrm{Na}$ uwage zasługuje ponadto fakt obowiązywania w grupie dyskusyjnej umownej pozycji społecznej poszczególnych użytkowników. Pierwszym sygnałem, że mamy do czynienia $\mathrm{z}$ osobą o wysokim statusie na forum, jest jej charakterystyka. Z ilustracji 4. dowiadujemy się, że osoba o nicku yaska_paska rejestrowała się na forum 450 razy. Poza tym zamieściła 392 posty. Jej status wyrażony został symbolicznie za pomocą gwiazdek. 
W tym wypadku mamy do czynienia z doświadczonym użytkownikiem. Taka osoba często bierze udział w dyskusjach prowadzonych na forum.

Nierzadko przejawem wyższego statusu społecznego są działania eksperckie (por. Mazurek 2005: 116). Doświadczeni członkowie najczęściej doradzają pozostałym użytkownikom, informują ich o bieżących wydarzeniach, takich jak np. koncert, spotkanie z członkami zespołu, zapowiedź nowej płyty itp. Grupowi „eksperci” starają się wyrażać uznanie bądź (uzasadnioną) dezaprobatę wobec zachowań innych uczestników dyskusji.

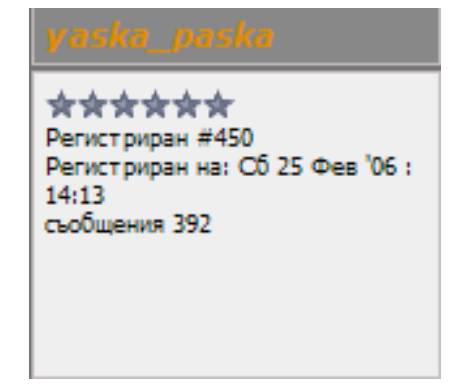

\section{Ilustracja 4. Okno informacyjne o użytkowniku grupy}

Pora przedstawić relację między komunikującymi się użytkownikami. Z technicznego punktu widzenia przekazywanie informacji między uczestnikami odbywa się poprzez zamieszczanie postów. Jakkolwiek pisanie i odczytywanie tekstów nie następuje w tym samym czasie, to jednak nie można zakwestionować pojęcia dialogowości, choćby z tego względu, że zarówno nadawca, jak i odbiorca wymieniają się rolami, tak jak się to odbywa w rozmowie typu face to face. Poza tym niejednokrotnie w jednej tylko dyskusji bierze udział więcej niż dwóch interlokutorów, co spełnia podstawowe kryterium dyskursu konwersacyjnego. W analizie dyskursu przyjmuje się zazwyczaj, że znakowa (złożona z elementów językowych i pozajęzykowych) reprezentacja zjawiska dyskursu zależy od sytuacji komunikacyjnej i przedstawia się jako zamknięty ciąg wypowiedzi (por. Taras 2006: 94). Rodzi się w tym miejscu pytanie, w jaki sposób podtrzymywana jest rozmowa na forum. Zacznijmy od tego, że wiele aktów komunikacyjnych w grupie dyskusyjnej przebiega $\mathrm{z}$ wykorzystaniem, poza podstawowym kodem języka naturalnego, innych systemów znakowych. Kod językowy bardzo często uzupełniają emotikony (od ang. emotion 'emocja' oraz icon 'obraz'), czyli znaki graficzne służące sygnalizowaniu stanów emocjonalnych nadawców komunikatu (por. Pisarek 2006: 51). Na tym ich funkcja się nie kończy, bowiem emotikony mogą z powodzeniem wzmacniać treści językowe, wyrażać stosunek nadawcy do treści (własnej) wypowiedzi, zastępować frazy opisujące czynności podejmowane przez nadawcę, a nawet wskazywać przynależność etniczną (por. Maliszewska 2002). Poprzez zastępowanie kodu kinezyjnego emotikony stają się elementem fatycznym w komunikacji. Warto nadmienić, że w komunikacji internetowej pojawia się spora ilość przyczynków do podjęcia dialogu i jego kontynuowania; już sama rejestracja do grupy dyskusyjnej wynika z nastawienia na dialog. Potrzeba rozmowy oraz uczestnictwa w grupie ma niewątpliwie swoje źródło w psychice.

\section{Analiza dyskursu konwersacyjnego w grupie dyskusyjnej}

Przejdziemy obecnie do opisania aktów komunikacyjnch, jakie obserwuje się w badanej grupie dyskusyjnej. Posłużymy się metodą analizy dyskursu konwersacyjnego (Kurcz 2005: 166-170), roszerzoną o funkcje tekstu - sterowanie i monitorowanie sytuacji (Beaugrande, Dressler 1990: 214). 
Poniżej prezentujemy fragment rozmowy na forum. Jak widać, bierze w niej udział ośmiu użytkowników. Tony_st rozpoczyna od zapowiedzi koncertu swojej ulubionej grupy muzycznej, który zostanie wyemitowany w telewizji. Nie wie przy tym, jaki to będzie koncert i dlatego stawia otwarte pytanie do pozostałych użytkowników. Formuła zapytania A вие? zakończona emotikonem ;-) ma zachęcić zarejestrowanych właśnie użytkowników do rozpoczęcia rozmowy.

\begin{tabular}{|c|c|}
\hline Tony_st & $\begin{array}{l}\text { Утре } 9 \text { септември /събота/ от } 23 \text { ч. по телевизия СКАТ ще излъчат концерт на } \\
\text { "наш'те хора". Разбрах, че е с продължителност един час. Не ми стана ясно } \\
\text { обаче, точно кой концерт ще изльчат, но важното е, че знам утре вечер какво } \\
\text { ще гледам...:) } \\
\text { А вие?;-) }\end{array}$ \\
\hline ani & $\begin{array}{l}\text { Може да е от някой Рокфест... По Скат от време на време изльчват записи от } \\
\text { подобни концерти:)) }\end{array}$ \\
\hline yaska_paska & $\begin{array}{l}\text { Според мен това е концерта от Созопол } 2002 \text { година! Често го излъчват по } \\
\text { СКАТ - бях го гледал веднъж посред нощите - сега ще е от "по-рано"....:-))) }\end{array}$ \\
\hline viki88 & значи с нетърпение ще чакам да 23ч,че да си пусна СКАТ ТВ :):):) \\
\hline btrcool & и аз ще мога да го хвана!!! :))) \\
\hline beemaya & $\begin{array}{l}\text { е,това е друго вече:) Благодаря ти Тони,ако не беше ти,пак нямаше да знам } \\
\text { какво се случва по телевизиите.Сега ще трябва само я открия тая телевизия от } \\
\text { по раничко;) }\end{array}$ \\
\hline viki88 & $\begin{array}{l}\text { за съжаление тоя канал го нямам:( искам само да кажа, че който ще го записва } \\
\text { после ако може да ми го даде да го изгледам:):):) пр гледане и после да } \\
\text { разказвате:) }\end{array}$ \\
\hline Tony_st & $\begin{array}{l}\text { Хихихихи, Мая, ще трябва да благодариш на майка ми, щот звъня } 4 \text { пъти да ми } \\
\text { напомни да не го изпусна... И аз, за не не забравя, наред с напомката, реших да } \\
\text { пиша и на вас.:-))) } \\
\text { Да, оказа се, че е концертът от } 2002 \text { от Созопол - Ясене, що ми се струва, че е } \\
\text { от Аполонията тогава? Или бъркам? }\end{array}$ \\
\hline vassy & $\begin{array}{l}\text { ъ..БТР не са ли били само веднъж на Аполония } 96 \text { или } 97 \text { не помня или } \\
\text { бъркам? }\end{array}$ \\
\hline yaska_paska & $\begin{array}{l}\text { Аз да кажа само, че вече го гледам тоя концерт за 2-ри път и все така имам } \\
\text { чувството че не гледам рок фест както пишеше зад гърбовете им а някъкъв } \\
\text { странен вариант на Тв дискотека...:-((( } \\
\text { Да ама само дето и ТВ дискотеките бяха по-хард, нали така Слаш?!! :-))) } \\
\text { Нашата дискотека ще е на } 21 \text { хаха :- })))\end{array}$ \\
\hline$S L A S H$ & абсолютно !!! \\
\hline
\end{tabular}

\section{Едночасов кониерт на Б.Т.Р.!}

Zastanówmy się, czy nadawca (Tony_st) nie tworzy tu określonego aktu mowy. W wypowiedzi Не ми стана ясно обаче, точно кой концерт ще излъчат, но важното е, че знам утре вечер какво ще гледам...:) А вие?;-) rozpoznajemy typowy akt illokucyjny, wyrażający intencję - Chce ogladać koncert $X$, tyle że nie wiem, jaki to będzie koncert. A $w y$ ?, jednak rozpatrując problem dokładniej, zauważymy, że wypowiedź stanowi też próbe wywołania na adresacie (adresatach) pewnych reakcji, tj. zamierzonego efektu perlokucyjnego. Na pytanie Tony_st uzyskuje kilka odpowiedzi, np. Може да е от някой Рокфест... (ani) czy Според мен това е концерта от Созопол 2002 година! (yaska_paska). Udzielanie odpowiedzi na pytania realizuje najistotniejszą funkcję grupy 
dyskusyjnej - wymianę informacji. Wypowiedź użytkownika beemaya reprezentuje akt illokucyjny ekspresywny, który powinien w rezultacie wywołać (implikować) określoną reakcję (efekt perlokucyjny) u odbiorcy o nicku Tony_st. Czasownikiem paradygmatycznym (czyli takim, który konstytuuje dany rodzaj aktu) jest w tym wypadku благодаря. Adresat poprawnie odczytał intencję - którą było nie tylko okazanie wdzięczności, lecz także sprawienie radości - i odpowiedział Хихихихи, Мая, щуе трябва да благодариш на майка ми, щот звъня 4 пъти да ми напомни да не го изпусна... И аз, за не не забравя, наред с напомката, реших да пиша и на вас.:-))) W następstwie odszyfrowania intencji Tony_st zareagował ekspresywnym Хихихихи. W tym samym tekście Tony_st potwierdza wcześniejszą odpowiedź otrzymaną od yaska_paska: Да, оказа се, че е кониертьт от 2002 от Созопол і zapytuje dodatkowo - Ясене, щуо ми се струва, че е от Аполонията (chodzi zapewne o festiwal sztuki w amfiteatrze „Apolonia” w Sozopolu) тогава? Или бъркам? Odpowiedź użytkownika yaska_paska jest uzupełnieniem wcześniejszej myśli. Tym razem przybiera jednak postać krytyki $А з$ $\partial a$ кажа само, че вече го гледам тоя кониерт за 2-ри пьт и все така имам чувството че не гледам рок фест както пишеше зад гърбовете им а някъкъв странен вариант на Тв дискотека....-((( Po niej następuje pytanie do innego użytkownika, które jest rozwinięciem wypowiedzi Да ама само дето и ТВ дискотеките бяха по-хард, нали така Слаш?!! :-))) Adresat (SLASH) doskonale rozumie kontekst wypowiedzi i reaguje tylko krótkim potwierdzeniem абсолютно !!!

Jeśli się chce przyjrzeć lepiej, jak przebiega dyskurs w grupie dyskusyjnej, można pokazać jego graficzny schemat, ukazujący pary przyległe. Oto jak mógłby on wyglądać:

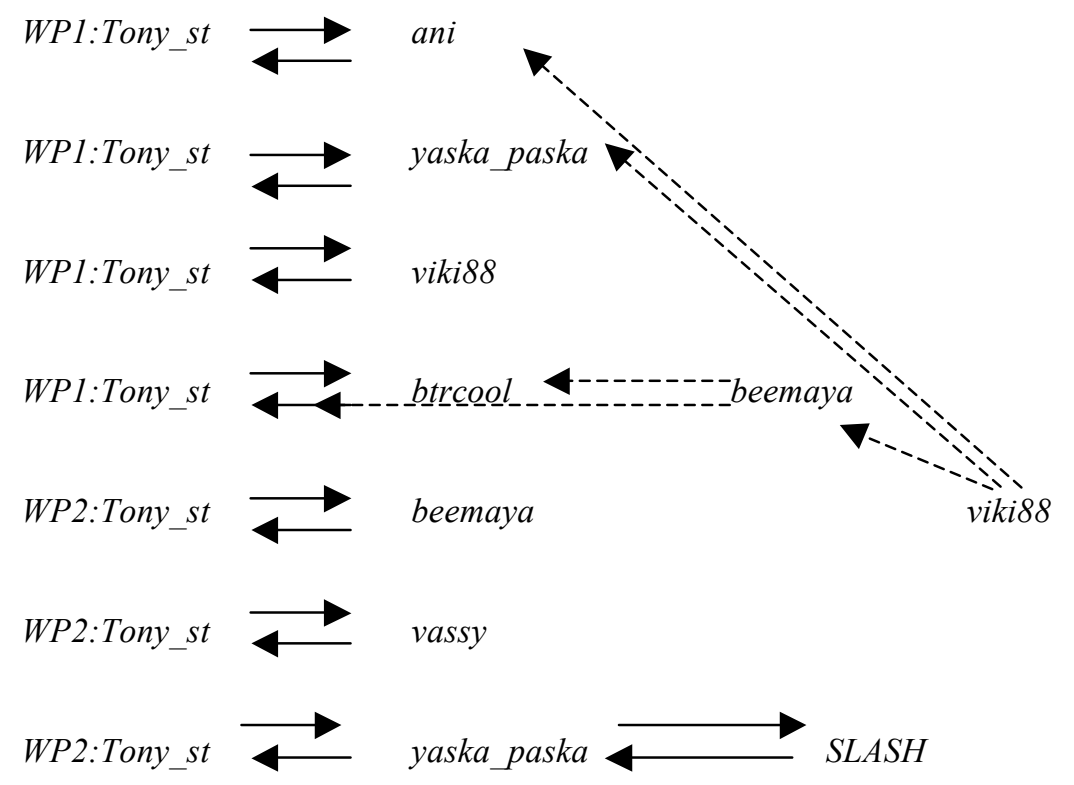

Za WP (wypowiedź) należy podstawić tekst wyprodukowany przez użytkownika Tony_st, liczby 1 i 2 oznaczają jego wypowiedzi. Strzałki odpowiadają relacji PYTANIEODPOWIEDŹ, jaka zachodzi między parą przyległą. Strzałki przerywane wskazują na dodatkowe wypowiedzi, które są pośrednio związane z WP1 lub WP2. Mają one wyłącznie kierunek jednostronny; są niejako produktem ubocznym dyskursu. Ciekawą sytuację komunikacyjną tworzą ostatnie wypowiedzi. Tony_st zadał pytanie, na które odpowiada użytkownik yaska_paska, kierując następnie dalszą część własnej wypowiedzi do użytkownika $S L A S H$, ten z kolei przekazuje krótką odpowiedź do yaska_paska. 
Jak już wcześniej powiedziano, wymiana informacji determinuje dyskurs w grupie dyskusyjnej. Kolejnym obserwowanym na forum zachowaniem językowym jest wyrażanie krytyki. Poniżej prześledzimy dialog, w którym podjęto krytykę zjawiska tzw. piractwa (muzycznego). Treść tej rozmowy odzwierciedla sposób myślenia użytkowników grupy, którzy właśnie dzięki (takim krytycznym) dyskusjom przyczyniają się niekiedy do ustanawiania swego rodzaju norm systemu aksjonormatywnego kultury organizacyjnej.

\begin{tabular}{|l|l|}
\hline Mitaka & iskam da popitam vseki na kakvo mnenie ima po temata??Naistina ot \\
oftetqva,no .... & все ми е тая дали ще си взема пиратка или оригинал....но ако трябва да \\
съм честна...оригинала е по-добър въвъ всички случаи:)макар, че \\
напоследък не си купувам нищо, а тегля от интернет:):):
\end{tabular}

$$
\text { piratstvoto - za ili protiv?? }
$$

Nietrudno zauważyć, że użytkownicy w powyższej dyskusji poprzez swoje wypowiedzi dążą do rozwiązania problemu (termin wprowadzam za $\mathrm{R}$. A. de Beaugrandem i W. U. Dresslerem), w tym wypadku będzie to wypracowanie opinii na temat piractwa. Funkcjami tekstu, które przyczyniają się do rozwiązania problemu w określonej sytuacji konwersacyjnej są monitorowanie sytuacji oraz sterowanie sytuacji. Pierwszy termin może być rozumiany jako opis sytuacji (podanie danych, opinii itp.), natomiast drugi wskazuje na prowadzenie rozmowy w sposób korzystny dla celów autora tekstu. Przyjrzyjmy się wybranym wypowiedziom. Rozmowę rozpoczyna Mitaka, pytając innych o zdanie na temat piractwa. Od początku viki88 konsekwentnie prowadzi sterowanie i monitorowanie sytuacji. Unika ona otwartej krytyki piractwa, potwierdza, że оригинала е по-добър въвъ всички случаи:) i natychmiast stosuje sterowanie sytuacji (w drugiej wypowiedzi), tłumacząc, że choć ma płyty ulubionego zaspołu, колкото до албумите-аз ги имам всичките от 1997 на дискове, to jednak nie są one w odpowiednim formacie i dlatego musi pozyskiwać utwory z Internetu, co subtelnie „zasłania” problem piractwa. Podobny zabieg przeprowadził yaska_paska. Na początku monitorował sytuację, krytykując piractwo. Przyznał, że kupował albumy zespołu Б.T.P., co już świadczy o sterowaniu sytuacji, poza tym ostatecznie prosi o definicję piractwa: Темата е хубава, но създателя 
и първо да уточни какво разбира под "пиратство" - защото интерпретациите в това отношение са доста... Użytkownicy, którzy podkreślają uczciwość wobec zespołu (kupują bądź kupowali tylko jego oryginalne albumy), nieświadomie wypracowują normę systemu aksjonormatywnego.

Wspomniane wcześniej działania eksperckie należą również do ważnych zachowań komunikacyjnych w grupie dyskusyjnej. Nie trzeba chyba dodawać, że przekazywanie przydatnych informacji spotyka się $\mathrm{z}$ powszechnym entuzjazmem pozostałych użytkowników. W prezentowanym poniżej poście Gluscevic ${ }^{\circledR}$ dzieli się informacjami, dbając o zachowanie wszystkich kryteriów poprawnego tekstu informacyjnego.

\begin{tabular}{|c|c|}
\hline Gluscevic ${ }^{\circledR}$ & 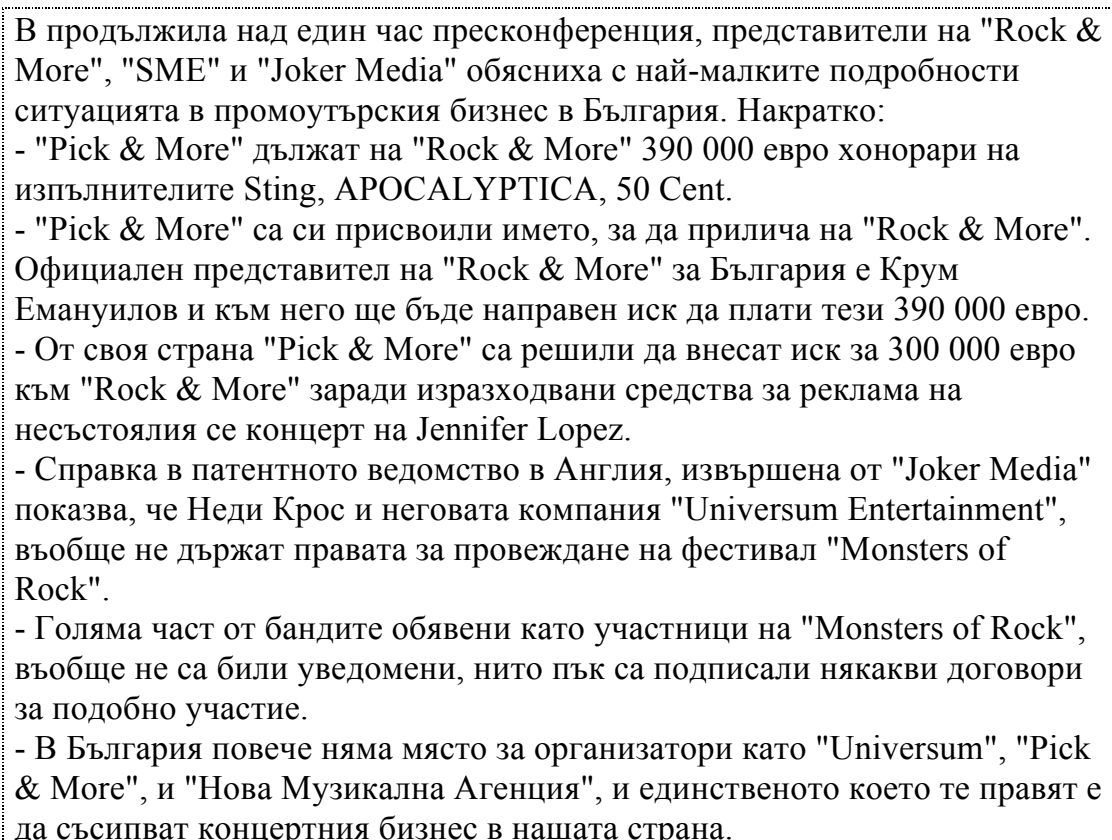 \\
\hline
\end{tabular}

\section{И отново за българските промоутъри}

Wydaje się, że poprawne pisanie tekstu na forum dyskusyjnym jest najczęściej procesem nieświadomym. Można tu poszukiwać odniesień do kompetencji językowej, która (jak zakłada I. Kurcz) ,jest w tym sensie utajona, iż o jej cechach wnioskujemy na podstawie zachowań językowych (werbalnych lub znaków manualnych) poszczególnych osób małych dzieci lub dorosłych" (Kurcz 2005: 33). Informacje, które podał Gluscevic ${ }^{\circledR}$ są komentowane na forum. Pozwala to wyciagnąć wniosek, że działania eksperckie mają wpływ na wcześniej opisane zachowania - dyskutowanie i wyrażanie krytyki, stając się istotną częścią dyskursu. Osoba dobrze poinformowana, która ma coś do powiedzenia, najczęściej rozpoczyna nowe tematy bądź służy radą innym użytkownikom. Komentarz viki88 do powyższego tekstu rozwija dyskusję.

\begin{tabular}{|c|c|}
\hline viki88 & $\begin{array}{l}\text { Знаеш ли, много си прав!!! } \\
\text { Аз това го разбрах, впоследствие отменените концерти, които бяха } \\
\text { "организирани" от Юниверсум и които така и не се състояха. } \\
\text { Може би единствените агенции, които държат на думата си са СМЕ и } \\
\text { Жокер медиа. Разбира се, това си е лично мое мнение!!! }\end{array}$ \\
\hline Gluscevic ${ }^{\circledR}$ & $\begin{array}{l}\text { И просто така за статистиката - отпадна и концерта на W.A.S.P. в София, } \\
\text { поради "отказ на Pick \& More да осъществи събитието"... }\end{array}$ \\
\hline beemaya & $\begin{array}{l}\text { добре,че в Каварна имаше концерт на W.A.S.P. } \\
\text { по късно,но имаше;) }\end{array}$ \\
\hline
\end{tabular}




\begin{tabular}{|c|c|}
\hline Gluscevic ${ }^{\circledR}$ & $\begin{array}{l}\text { Еми аз вече като разбера за концерт преди дата, цена на билети и пр. ще } \\
\text { гледам в кой град ще е, за да не храня напразни надежди ако не е в } \\
\text { Каварна... Цонко кмет на София! :)))) }\end{array}$ \\
\hline DraKa & $\begin{array}{l}\text { Прекрасна идея! А после ще го направим и президент. Така България ще } \\
\text { стане рок-центъра на света, всички групи ще правят концерти тук и ..... } \\
\text { мечти... }\end{array}$ \\
\hline
\end{tabular}

\section{$4 \quad$ Język w grupie dyskusyjnej}

Analiza subkodu leksykalnego, stylistycznego i syntaktycznego pozwala m.in. na obserwację uzusu współczesnej bułgarszczyzny. W warstwie leksykalnej pojawiają się neologizmy będące zapożyczeniami z języka angielskiego, typu есемес (ang. sms) i джиесем (ang. gsm) - w postaci fonetycznie zapisanego skrótu, dyrewatami ujemnymi нет $\leftarrow$ интернет, комп $\leftarrow$ компютьр, rzeczownikami urobionymi od czasowników, np. напомка (od напомням), обложка (od облагам) itp.

Dużą grupę stanowią wyrazy potoczne, np. rzeczowniki нехранимайковци, мизерия, чалгаджия, czaowniki кефя (z prefiksami из-, на-, под-), майтапя се, partykuły ами, бе, eü, xaŭde itp.

Ważnym elementem subkodu leksykalnego są wyrazy slangowe, bezpośrednio związane z kręgiem zainteresowań użytkowników omawianej grupy dyskusyjnej, np. rzeczowniki форумец, пич, лайф, съпорт, турне, фус, соло, флор, czasowniki чатя си, базикам се, купонясвам itp. Wiele takich leksemów wchodzi w skład związków frazeologicznych, np. метьл кючек, смешен музикален пазар, як китарен риф, по-хеви парчета, страхотни парчета, откачен и безсмислен рок, направя невероятно шоу itp.

Subkod stylistyczny i syntaktyczny odzwierciedla spontaniczny styl wypowiedzi. Dominują krótkie, proste zdania. Użytkownicy badanej grupy dość często lekceważą reguły interpunkcyjne oraz delimitacji tekstu. Zdania niejednokrotnie nie mają początku ani końca. Ponadto znaczna ilość błędów w zapisie poszczególnych słów świadczy o małej dbałości o edycję tekstu; uchybienie to wynika prawdopodobnie z szybkiego tempa pisania na klawiaturze.

\section{Podsumowanie}

Przytoczone przykłady językowych zachowań użytkowników naśladuja potoczne, spontaniczne, niekiedy wulgarne wypowiedzi ustne w czasie rzeczywistym. Uczestnicy dyskursu mają określone oczekiwania (znają cele uczestnictwa w grupie dyskusyjnej, chcą rozszerzać wiedzę o ich ulubionym zespole, jak i o muzyce w ogóle) wzajemnie motywują się do podejmowania tych zachowań (poszukują tematów do dyskusji, doradzają sobie nawzajem, podejmują się krytycznej oceny zjawisk związanych z rynkiem muzycznym itp.), które kształtują językowy obraz świata grupy dyskusyjnej, poświadczający językową tożsamość członków grupy. Zaproponowana metoda analizy dyskursu konwersacyjnego potwierdza przede wszystkim społeczny charakter grupy dyskusyjnej poprzez odtworzenie występujących w niej zachowań językowych o charakterze aksjolingwistycznym, takich jak wyrażanie szacunku wobec języka grupy i posługiwania się nim w komunikacji, mimo że pod względem normatywnym wypowiedzi prezentują małą dbałośc o kulturę słowa. Niemniej jednak ujawniony w języku system aksjonormatywny tej grupy dyskusyjnej zdaje się być wartością przyjmowaną przez ogół użytkowników. 


\section{Bibliografia}

Beaugrande, R.A. de, Dressler, W.U. 1990. Wstęp do lingwistyki tekstu, tłum. A. Szwedek. Warszawa: Państwowe Wydawnictwo Naukowe.

Grabias, S. 2003. Język w zachowaniach społecznych, Lublin: Wydawnictwo Uniwersytetu M. Curie-Skłodowskiej.

Grzenia, J. 2006. Komunikacja językowa w Internecie. Warszawa: Wydawnictwo Naukowe PWN.

Kalisz, R. 1993. Pragmatyka językowa. Gdańsk: Wydawnictwo Uniwersytetu Gdańskiego.

Kurcz, I. 2005. Psychologia języka i komunikacji. Warszawa: „Scholar”.

Maliszewska, A. 2002. Wirtualna buźka. Modyfikująca rola znaków graficznych w komunikacji internetowej. w: Tekst w mediach, pod red. K. Michalewskiego, Łódź: Wydawnictwo Uniwersytetu Łódzkiego.

Mazurek, P. 2003. Internetowa grupa dyskusyjna, „Kultura i Społeczeństwo”, nr 1.

Lipińska, J. 2004. Rola kultury organizacyjnej w grupach dyskusyjnych. w: Edukacja medialna. Nowa generacja pytań $i$ obszarów badawczych, pod red. M. Sokołowskiego, Olsztyn:Oficyna Wydawnicza „Kastalia”.

Olejnik, K. 2005. Wspólnoty w Sieci. w: Umyst - Ciało - Sieć, pod. red. E. Stawowczyk, W. Chyły, Poznań: Wydawnictwo Naukowe Uniwersytetu Adama Mickiewicza.

Пашов, П. 2005. Българска граматика. София: Издателска Къща „Хермес”

Pisarek, W (red.). 2006. Stownik terminologii medialnej. Kraków: UNIVERSITAS. 